\title{
Effective Science Learning through Restructuring and Reconstruction from the Knowledge Soup
}

\author{
Kunle Oke Oloruntegbe \\ Science and Technical Education, Adekunle Ajasin University, Akungba-Akoko, Ondo State, Nigeria
}

\begin{abstract}
Authentic and meaningful science learning can be achieved when students are given the opportunity to organize, reorganize and restructure their learning from the knowledge soup. This is the focus of this paper that investigated how the performance of undergraduate science students could be enhanced when they construct and monitor their own learning individually and in team. It was a case study of 22 integrated science students' learning of Organic Compounds I and II courses, facilitated and monitored in two semesters. The students were assigned specific tasks individually on the course outlines which they presented one after the other in two hours' lectures a week that lasted for 12 weeks in the first semester. In the second semester, tasks were assigned on team (5 groups of 4 or 5) basis and were presented as projects and seminars on power points followed by discussion and interactive sessions two hours a week for another 12 weeks. Instruments for data collection included the moderated semester examination questions with marking schemes, class assignments and tests which assessed the depth of individual and team works, skills of presentation and quality of contributions to class discussions. The analysis of data revealed good performances in the two semesters but a better one during the second semester when the students worked in teams. Appropriate conclusion was drawn and recommendations made. This study calls for reawakening of learners' initiated, student-centered pedagogy which is gradually fading away in our science classrooms.
\end{abstract}

Keywords: Construction and restructuring of knowledge, knowledge soup, individual and team work, authentic science learning

\section{Introduction}

Research has shown that students often construct their own theories about how the natural world works and come to classroom with varying experiences, with ideas about, and explanations of the natural world. It is a well-known fact too that these personal theories and explanations are most of the times contrary to scientific views (Osborne \& Freyberg, 1985) and may stand in the way of learning something new (Vosniadou, 2001). These children explanations have been variously labeled as alternative conceptions, misconceptions, naïve conceptions and children science (Ozmen, 2007). No matter how vague or incorrect this children science may be, appropriate reorganization, modification, extension and elaboration by expert teachers could result in meaningful and authentic science learning (Meyer, 2004). Oloruntegbe (2000) posits that no children come to a lesson empty headed, something empty, ready to be filled so to say, but they come in with different prior knowledge and intuitive ideas of the topic or concept at hand. Restructuring these ideas in a way similar to "unpacking" or "repacking" a bag will make them appropriately fit and accommodated into the existing cognitive schemata.
The methods of science delivery of many teachers show that they do not subscribe to the idea of children learning through reconstruction of knowledge and restructuring of ideas (Meyer, 2004). They tend to see students as coming empty to the class and ready to be filled in a way a jug is being filled with liquid. This view sees learning as additive and not constructive, and their methods can be described as filling the jug rather than unpacking or repacking the bag. Sadly enough, personal observation reveals science classrooms that are dominated by teachers who look more or less as actors and actresses, and students who are passive recipients of teachers' lecture notes and textbook authors' ideas. Studies like that of Mewhinney (2010) further reveal that the traditional teaching methods in higher education are no longer meeting students' educational needs. There is the need for best practices and best pedagogical patterns to meet the needs of today students.

Consideration of teachers' perspectives, particularly their ability to use students' prior knowledge to achieve meaningful learning in science is very important. Research has shown that learning is enhanced when teachers pay close attention to the prior knowledge of the learners and use this as the starting point for instruction (Vosniadou, 2001). 
Teachers do not simply need to know that students know something about the topic to be introduced. They need to investigate students' prior knowledge in details so that false beliefs and misconceptions can be identified and replaced. Teachers may need to go back to cover important prerequisite materials or ask the students to do some preparatory work on their own.

What then is this 'bag' that needs repacking? This can be defined as "experienced-based explanations" that each learner constructs from a "knowledge soup" which in turn represents a range of events, ideas, science phenomena, stories from peers, parents, internet, and social media acquired on a daily basis.

Varying children's views of scientific phenomena like atoms and molecules have been recorded (Griffiths \& Preston, 2006, Doran, 2006; Peterson, Treagust \& Garnett, 2006). For instance, misconceptions relating to structure, shape, size, weight, and animistic perceptions of atoms were reported among Grade-12 students by Griffiths and Preston (2006). Such views need be refined as suggested by Roschelle (1995) who sees science as the refinement of prior knowledge, and reorganized in line with the submission of Ozome (2007) that learning about science in a meaningful way involves realizing, reorganizing, or replacing existing conceptions to accommodate new ideas. This is akin to the conceptual change of the constructivists theorists.

All theories of knowledge acquisition and cognitive development including that of Piaget also assume that a person's potentials can only be perfected and brought to use if learning opportunities are provided by the environment (Sterm, 2005). This suggests a strong relationship the environment has on cognitive development. Apart from buttressing the environmental effect on learning, Mewhinney's (2010) and Lantzky's (2010) POGIL, Process Oriented Guided Inquiry Learning, equally stressed the relative role of cooperative learning in shaping science activities in the classrooms. According to Mewhinney (2010) and Lantzky (2010) learning environments can be competitive, individualized, or cooperative. Research has documented that relative to other situations, students learn more, understand more, and remember more when they work together. Students tend to be more at home among themselves, course mates, and manifest more positive attitudes regarding the subject areas, course, and instructors. Students working in a team environment are more likely to acquire essential process skills such as analytical thinking, problem solving, teamwork, and communication (Johnson, Johnson and Smith, 1991). These all point to one direction, that students would gain more, be able to retain more and transfer leaning much easily in other novel situations if such learning is constructed from the knowledge soup and on team basis. This case study was conducted based on these factors of restructuring of ideas and reconstruction from the knowledge soup on one hand and the employment of team work on the other among science undergraduates.

\section{Aim of the Study}

This paper reports a research work, a case study conducted with undergraduates of Adekunle Ajasin University, Ondo State, Nigeria. It investigated how the performance of the students could be enhanced when they constructed and monitored their own learning individually and in teams. Two research questions were raised which are: would the students perform better when they construct and monitor their learning individually or in teams? What categories of skills are students likely to acquire in both groups? And one null hypothesis of no significant difference in the performance of the students in the two semesters was formulated.

\section{Methodology}

The research was a case study that made use of 22 undergraduate integrated science students (6 males and 16 females) of Adekunle Ajasin University, Ondo State, Nigeria in2011/2012 session. Two courses, ISE 301 and ISE 308, Organic Compounds I and Organic Compounds II were covered respectively in First and Second Semesters of the session. In ISE 301, the students were assigned specific tasks individually on the course outlines which they presented one after the other before lectures that lasted 12 weeks. In ISE 308, tasks were assigned on team ( 5 groups of 4 or 5 ) basis and were presented as projects and seminars on power points followed by discussion and interactive sessions, all lasted for another 12 weeks of the Second Semester. This investigator facilitated the students' learning in the two semesters. Instruments for data collection included the moderated semester examination questions with marking schemes, class assignments and tests which assessed the depth of individual and team work, skills of presentation and quality of contribution to class discussions. Topics covered in ISE 301 are classification of organic compounds, reactions and uses of hydrocarbons; petroleum industry which included a term paper on Prospects and Problems of Fifty years of Oil Exploration in Nigeria; aromatic hydrocarbons; haloalkanes and alkanols. On the other hand, ISE 308 covered alkanals and alkanones; alkanoic acids; amine; amino acids and proteins; carbohydrates and cellulose, lipids and vitamins. The data collected were analyzed using mean, standard deviation and t-test inferential statistic. 


\section{Results}

The performances of the students at the end of the two semesters were compared.

The mean score of the students in the second semester was higher than of the first. There was also a significant difference (at $P<.05)$ in the two mean scores, meaning that the students' performance was better in the second semester. The scores were equally closer in the second semester judging from the smaller standard deviation. This means that a greater number of the students, particularly females gained more in the second semester work. Observations during the two semesters show that there were more students' involvements, better presentation particularly from the females. All the female student presenters were articulate in their presentation. They were appropriate in the use of chemical principles; equations and nomenclature. They also were able to connect much aspects of the knowledge to real life experiences, which made the presentation and interactive sessions more lively. One male presenter had problem in the use appropriate chemical explanations and pronunciation of the organic compounds. In all, there were more robust interactions, comments and critique of presentation in the second semester when students worked in teams

Table 1. Mean, Standard Deviation and t-test of students' scores in the two semesters.

\begin{tabular}{|c|c|c|c|c|c|c|}
\hline Variable & $\mathrm{X}$ & SD & $\mathrm{n}$ & df & $\mathrm{t}_{\text {calculated }}$ & $\mathrm{t}_{\text {critical }}$ \\
\hline First Semester & 66.2424 & $\begin{array}{ll}5.9660 & 22\end{array}$ & 42 & 8.94 & 2.00 & \\
\hline Second Semester & 72.2581 & $3.2454 \quad 22$ & & & & \\
\hline
\end{tabular}
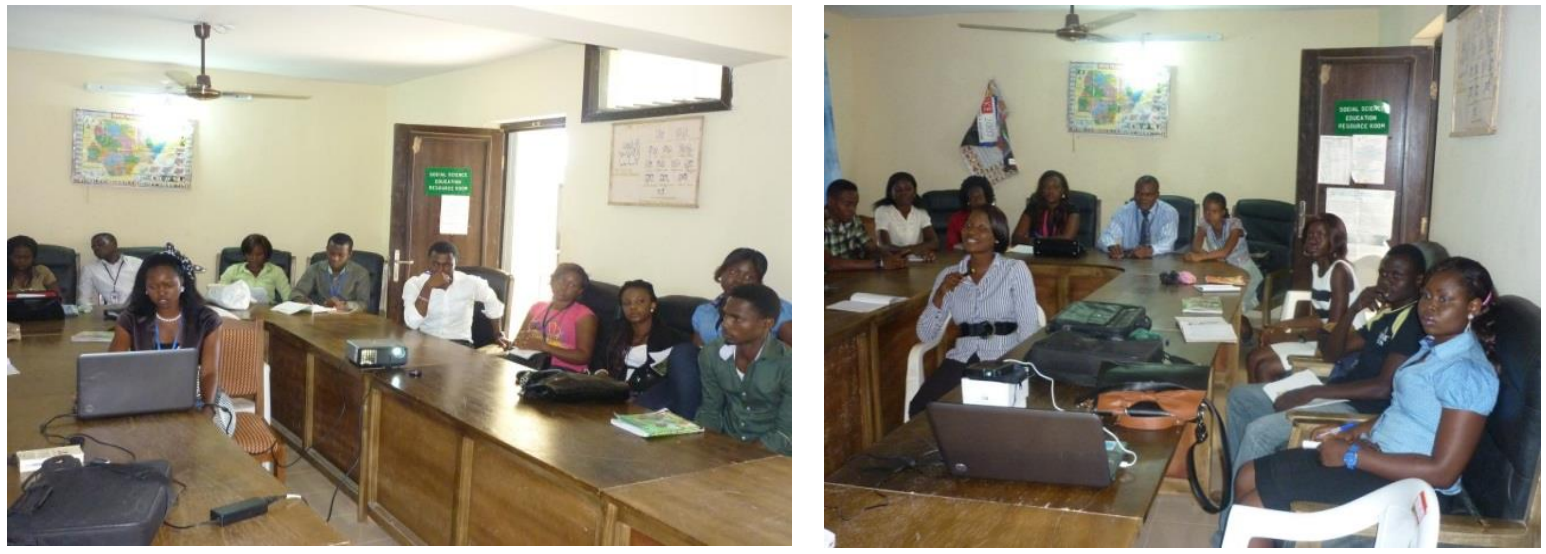

Figure 1. Students at group presentations
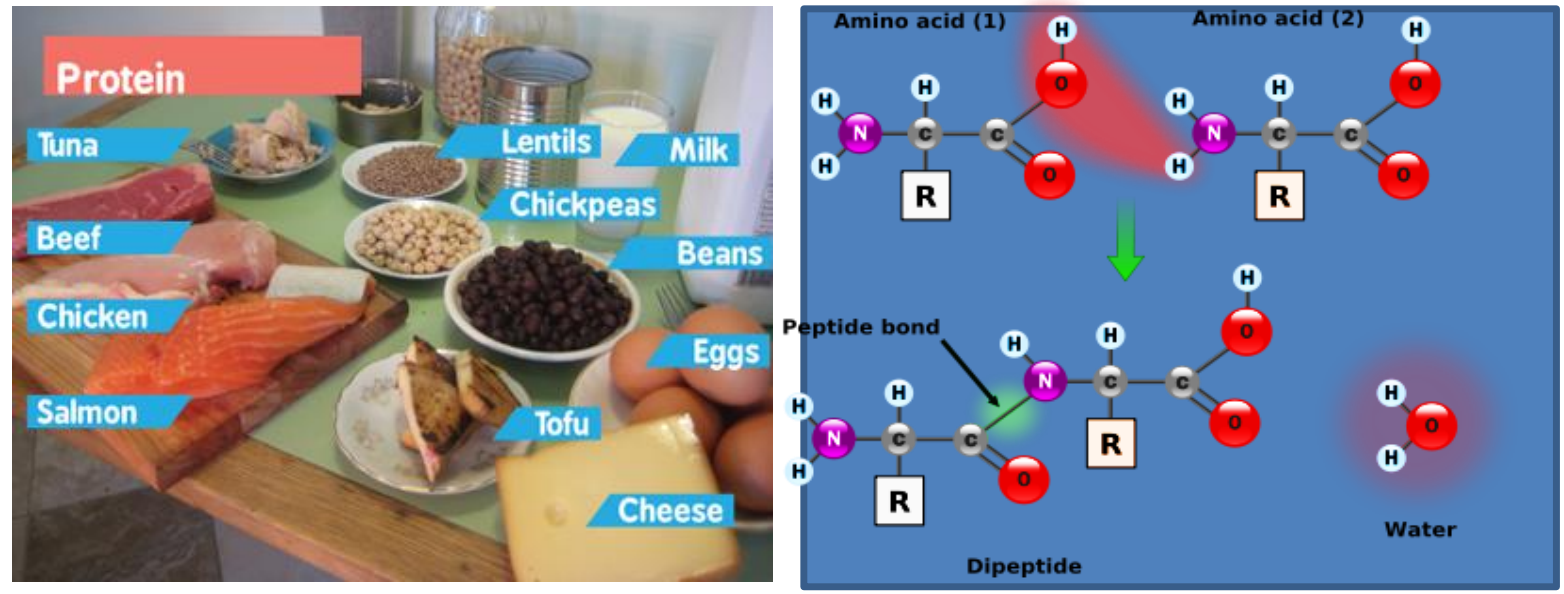

Figure 2. Sample slides from students' presentation on amino acid and proteins 


\section{Conclusion and Recommendations}

From the results, it could be seen that the students performed well in the two semesters when the students did much of their learning with the teacher serving as a facilitator. However, the performance was better in the second semester when students learned in teams in addition. Much of the students' potentials were brought to fore in terms of ability to uncover learning on their own, and in the display of skills of presentation, persuasive communication, reflective and critical thinking. The students equally manifested appropriate scientific attitudes of responsibility, rationality, objectivity, parsimony, suspended judgment and positive attitude to failure. They also developed leadership and team spirits. It can be concluded that authentic and meaningful science learning can be achieved when the students are given the opportunity to organize, reorganize and restructure their learning individually and better still, in teams.

Whereas there is always the search for best practices and best pedagogical patterns in science classroom teaching and learning, the pattern examined and suggested in this study provides one of the leads in this search. As noted earlier, most university classrooms are still dominated by the traditional age-long strategies like expository, teachers-initiated and teacher-dominated activities that render students passive or less active partners. Such strategies can hardly meet the needs of today technology-driven, and hands-on, hearts-on science classroom. The facilitative effect of this study is an indication that student-initiated activity and team learning is one of the best pedagogical patterns needed in this dispensation. It was therefore recommended that science teachers should employ strategies unfolded here in their classroom teaching for better students' performance.

\section{References}

Doran, R.L. (2006). Misconceptions of selected science concepts held by elementary school students. Journal of Research in Science Teaching. 9(2),127-137.

Griffiths, A. K. \& Preston, K. R. (2006). Grade-12 students' misconceptions relating to fundamental characteristics of atoms and molecules. Journal of Research in Science Teaching. 29, (6), 611-628.

Johnson, D.W., Johnson, R.T. \& Smith, K.A. (1991). Active Learning: Cooperation in the college classroom. Edina, MN.

Lantzky, K. (2010). Increases in student scientific reasoning skills in the POGIL classroom. Book of Abstract of the $21^{\text {st }}$ Biennial Confrence on Chemical Education, University of North Texas, Denton, USA, August 1-5, 2010.

Mewhinney, T. (2010). Process oriented guided inquiry learning. book of abstract of the $21^{\text {st }}$ Biennial Conference on Chemical Education, University of North Texas, Denton, August 1-5.

Meyer, H. (2004). Novice and expert teachers' conceptions of learners' prior knowledge. Wiley Inter Science, Retrieved from: www.interscience.wiley.com.

Oloruntegbe, K.O. (2000). Effect of teachers' sensitization on students' acquistion of science process skills and attitudes. A Doctoral Thesis of Faculty of Education, University of Benin, Nigeria.

Osborne, R. \& Freyberg, J (1985). Learning in science: The implication in children's science. Heinemann, London

Ozmen, H. (2007). The effectiveness of conceptual change texts in remediating high school students' alternative conceptions concerning chemical equilibrium. Asia Pacific Education Review, 8, 3, 413-425.

Peterson, R.F.; Treagust, D.F. \& Garnett, P. (2006). Development and application of a diagnostic instrument to evaluate grade11 and -12 studnts' concepts of covalent bonding and structure following a course of instruction. Journal of Research in Science Teaching.

Roschelle, J. (1995). Learning in interactive environment: Prior knowledge and new experience. In J.H. Falk \& L.D. Dierking (Eds) Public Institutions of Personal Learning: Establishing a Research Agenda. Washington, DC: American Association of Museums, 37-51.

Stern, E. (2005). Knowledge restructuring as a powerful mechanism of cognitive development: How to lay an early foundation for conceptual understanding. PedagogyLearning for Teaching. The British Psychological Society, BJEP Monograph Series II, 3, 155-170

Vosniadou, S. (2001). How children learn. In Walberg, H.J. (Ed) International Academy of Education, Educational Practices Series, University of Illinois, Chicago. 